\title{
ARE MORPHOLOGY AND ENVIRONMENT CORRELATED WITH MALE DWARFISM IN PLEUROCARPOUS MOSSES?
}

\section{ЕСТЬ ЛИ СВЯЗЬ ВСТРЕЧАЕМОСТИ КАРЛИКОВЫХ МУЖСКИХ РАСТЕНИЙ У БОКОПЛОДНЫХ МХОВ С МОРФОЛОГИЕЙ И ЭКОЛОГИЕЙ ВИДОВ?}

\author{
LARS HEDENÄS ${ }^{1} \&$ IRENE BISANG ${ }^{1}$ \\ ЛАРС ХЕДЕНАС ${ }^{1}$, ИРЕН БИСАНГ ${ }^{1}$
}

\begin{abstract}
Dwarf males in mosses are restricted to certain lineages and have been proposed to be associated with epiphytism and subtropical environments. Here we explore which morphological and environmental characteristics are associated with male dwarfism in a set of 528 pleurocarpous mosses that represent the different lineages, habitats, and climatic conditions found in the world. We evaluate differences in frequencies of states for 48 morphological characters and for occurrences in different environments among species that are monoicous, dioicous without dwarf males, and dioicous with obligate or facultative dwarf males. An ambiguous picture emerged regarding which morphological characters or environmental parameters correlate with male dwarfism, indicating that dwarf males evolved in phylogenetically widely spread groups of pleurocarpous mosses that are not characterized by common characters or environments. Dioicous species with dwarf males were correlated with broad and imbricate leaves, short and wide marginal leaf cells, differentiated, but not inflated alar cells that relatively often consist of more than one cell layer, and patent or recurved upper portions of the inner perichaetial leaves. Such species were also more frequent than expected in temperate montane environments and in non-wetland habitats. Further studies of the evolution of dwarf males among (pleurocarpous) mosses should in a first step focus on these characters and environments. Differences between monoicous species and the two dioicous categories were numerous, including 18 characters between monoicous and dioicous species with dwarf males and 17 between monoicous and dioicous ones lacking dwarf males. Species with dwarf males were thus not more similar to monoicous than to dioicous species lacking dwarf males despite that they are sometimes called 'pseudautoicous'.
\end{abstract}

Резюме

Карликовые мужские растения у мхов встречаются только в определенных группах и, как считалось, приурочены в значительной степени к эпифитному образу жизни и чаще встречаются в субтропиках. Проведено исследование корреляции морфологических признаков и особенностей местообитаний с наличием карликовых мужских растений на выборке из 528 видов бокоплодных мхов из различных эволюционных линий, всех возможных биотопов и регионов мира. Оценивались 48 морфологических признаков у видов, которые подразделялись на 3 группы: однодомные, двудомные с карликовыми мужскими растениями (облигатными или факультативными) и двудомные без таковых. Показана в целом достаточно неопределенная картина, связанная с тем, что карликовые мужские растения возникали неоднократно в разных эволюционных группах и не имеют выраженной корреляции с общей морфологией видов и их экологией. Наличие карликовых мужских растений коррелировало лишь с немногими признаками, в числе которых широкие и черепитчатые листья, короткие и широкие клетки края листа, дифференцированные, но не вздутые клетки углов основания листа, которые чаще многослойные, а также далеко отклоненные до отогнутых верхушки перихециальных листьев. Доля ложнооднодомных видов повышена в горных районах умеренной зоны; кроме того, они определенно избегают переувлажненных местообитаний. Указанным признакам следует уделять особое внимание при дальнейшем изучении карликовых мужских растений в пределах отдельных групп (бокоплодных мхов). Вместе с тем, статистически значимые отличия были найдены между однодомными и ложнооднодомными видами по 18 признакам, и по 17 признакам между однодомными и настоящими двудомными видами. Таким образом, общий уровень различий между однодомными и настоящими двудомными растениями и между однодомными и двудомными с карликовыми мужскими растениями оказывается сходными. То обстоятельство, что последние часто называют ложнооднодомными, создает ложное представление о том, что этот половой тип в определенном смысле более сходен с однодомными растениями.

KEYWORDS: adaptation, character state, gametophyte, habitat, sexual system

1 - Swedish Museum of Natural History, Department of Botany, Box 50007, SE-104 05 Stockholm, Sweden. E-mail: lars.hedenas@nrm.se; Irene.bisang@nrm.se 


\section{INTRODUCTION}

The frequency and biological significance of dwarf males, especially in pleurocarpous mosses, has received considerable attention during the last years (Hedenäs \& Bisang, 2011, 2012; Rosengren \& Cronberg, 2014; Rosengren et al., 2014). Male dwarfism is an extreme form of female-biased sexual size dimorphism that occurs in many taxonomically widely different organism groups (Ghiselin, 1974; Vollrath, 1998). Among land plants, it is confined to mosses, where it has evolved in several unrelated lineages (Hedenäs \& Bisang, 2011; Ramsay, 1979). In mosses, dwarf males are minute plants that germinate from spores on parts (leaves, stems, tomentum) of the normal-sized female plant, remain attached and produce sexual branches during their usually annual life cycle. This sexual condition, also known as nanandry, phyllodioicy, or pseudautoicous, occurs in $25-50 \%$ of the dioicous pleurocarpous mosses, is frequently facultative, and has been shown to be essential for sexual reproduction and sporophyte production of these species. Morphological features and environmental characteristics associated with the occurrence of dwarf males in mosses have been addressed occasionally (Ernst-Schwarzenbach, 1939; Hedenäs \& Bisang, 2011; Pichonet \& Gradstein, 2012; Ramsay, 1979), but not in a phylogenetic context, with the exception of the analysis by Pedersen \& Newton (2007) on Ptychomniales. These studies, however, dealt with only a limited number of characters. A more comprehensive overview of the character variation and habitat requirements, and a wider species selection are required, to reveal the traits that are of potential interest to further phylogenetic studies of the evolution of male dwarfism. This will provide clues to why dwarf males evolved in certain species and how they affect the species' life cycles.

When organisms sharing a particular biology display distinctive morphological and anatomical structures or occur in specific environments, likely partly a result of a suitable physiology, this is often considered to be a result of adaptations. This assumes that the structures or physiological traits are apomorphic features which evolved as a direct response to natural selection (Arnold, 1994; Coddington, 1994). Many such features are instead exaptations. Although such characteristics are advantageous in a particular way at a specific time they were not directly selected for that function (Arnold, 1994). Other character states, that are selectively neutral in a certain environment, could have evolved by genetic drift or as adaptations in an ancestor of a particular species and subsequently become redundant when the descendants switched to a new habitat. Such neutral states often remain for a period of time before they are randomly eliminated, which is referred to as 'phylogenetic time lags' (Harvey \& Pagel, 1991). When pleiotropy is involved, states may even be disadvantageous if another feature, connected with the negative one, is relatively more strongly advantageous.
To correctly assess whether a certain characteristic, or state, that is exclusive to or especially common in species with a specific biology, the phylogenetic history of the species bearing this trait must be considered. Species with a shared phylogenetic history are likely to occur in similar habitats and to share character states that evolved in their ancestors. This likeness could be due either to the sole fact that they share the same ancestor (Bisang et al., 2014), or the similarity could sometimes be even more prominent because of phylogenetic niche conservatism (Losos, 2008). The latter implies that closely related species are ecologically more similar than should be expected from unconstrained evolution, due to the evolution of new species in unused ecological space within their habitat (Harvey \& Pagel, 1991) and problems to escape from their ancestral niche into habitats where other organisms are already better adapted (Losos, 2008). Thus, simple comparisons of the relative frequencies of character states in different habitats, without phylogenetic correction, often lead to erroneous conclusions regarding if states are true adaptations or not. One goal of modern phylogenetic research is therefore to unravel how characters evolved in the context of adaptations to the environment (e.g., Eggleton \& Vane-Wright, 1994; Harvey \& Pagel, 1991; Vilhelmsen \& Turrisi, 2011). Several studies of potential character adaptations in bryophytes in a phylogenetic context have been published (e.g., Ho, 2010; Olsson et al., 2009; Pedersen \& Newton, 2007; Vanderpoorten et al., 2002; Vanderpoorten \& Jacquemart, 2004).

The study of the evolution of adaptations requires three prerequisites. First, we need reliable phylogenies of the group of interest. Second, an adequate knowledge of the features which evolution is investigated, such as the morphology, physiology, or habitat preferences of the members of the studied group, is indispensable. Third, the formulation and testing of more general hypotheses of adaptations, valid beyond the focal study group, relies on trustworthy information regarding the distribution of the studied characteristics among habitats in a wider taxonomic context (Hedenäs, 2012).

In the present paper we explore whether different sexual systems in pleurocarpous mosses are associated with specific character states and environmental conditions. We ask: i) do the states of 48 structural, mainly gametophytic characters differ among three different sexual systems (monoicous, dioicous lacking dwarf males, dioicous with dwarf males), and ii) do the frequencies of species of each sexual system differ under different environmental conditions? We present a general set of structural traits that are correlated with male dwarfism, and therefore potentially represent pre-adaptations for it, and describe environmental conditions under which dwarf males are likely to evolve. They provide a basis to reveal if dwarf male evolution was triggered by the evolution of certain structural traits or the exploitation of particular environments. The latter re- 
quires that the events are, in a later step, placed in a phylogenetic context to evaluate their relative timing. Moreover, based on the present results, future studies of dwarf males in pleurocarpous mosses will be more correctly related to the habitats in which they are most frequent.

\section{MATERIAL AND METHODS}

Species and parameters. This investigation is based on observations of 528 pleurocarpous moss taxa, mostly considered distinct at the species level up to 2010 . We consider it unlikely that later nomenclatural changes or taxonomic conclusions, such as synonymisations or splits of taxa, should affect the presented results. Subspecies or varieties were included only for Catagonium nitens and Isothecium myosuroides and the two subspecific taxa are included in the numbers of species discussed in the paper. The species are classified according to their sexual system as monoicous (MON), dioicous, dwarf males absent (DIA), and dioicous, dwarf males present (DIP; often the dwarf males are facultative) (Appendix 1; where authors of Latin names are provided). The number of studied species (209 MON, 236 DIA, 83 DIP) corresponds to $8-10 \%$ of the known pleurocarpous moss species (cf. Bell et al., 2007; Frey \& Stech, 2009), representing the different lineages, habitats, and climatic conditions found in the world.

Besides the classification as to sexual systems, each species was assigned to the vegetation zones it occurs in and to its general habitat or habitats. Vegetation zones or habitats with too few occurrences for statistically meaningful comparisons were excluded. The species were also categorized as either epiphytes or non-epiphytes and as growing in dry or wet habitats. Details regarding the vegetation zone and habitat categories are found in Table 1 and Hedenäs $(2001,2012)$. The total number of occurrences in the different categories exceeds the number of species included because many species are found in more than one habitat, and some individual species exhibit more than one state of a character, for example branching patterns. We considered it more correct for the purposes of the present study to include all habitats where a species occurs regularly than to arbitrarily decide that a high number of occurrences indicate typical requirements.

Characters. The basis of the present analyses is a comprehensive data matrix for pleurocarpous moss characters. In all species LH personally studied most of the characters. In rare cases the information was completed from the literature (see Hedenäs, 2001). This keeps potential systematic errors similar throughout the data set and the comparisons are more reliable than when, for example, information is compiled from different floras. We selected a set of 56 character groups (e.g., leaf shape, costa, leaf cell ornamentation), which we considered potentially relevant for the evolution of dwarf males and which comprised mainly morphological and anatomical characters of the gametophyte. From these character groups, we extracted 39 qualitative (1-39) and nine quantitative (Q1-Q9) characters that were biologically meaningful for comparing the three sexual systems. The characters, and for qualitative ones their recognized states, are listed in Tables 2 and 3. We included six features of the perichaetia, since these may affect fertilisation success. We also included spore size (spores are next generation gametophytes) which influences spore dispersal distance and possibly also how easily a spore can attach to a female plant. Most sporophyte features are unlikely to affect the evolution of dwarf males. Thus, only seta length and capsule orientation were considered since these probably influence spore dispersal. Characters where one of two possible states occurred in only one or a few species were excluded. We recorded the state of each selected character for every species where it could be scored. Ambiguous scores of states, for example, when a character was so variable within a species that it could not be referred to either of two states, were excluded from the comparisons.

Characters and states were defined primarily for their potential relevance for the evolution of male dwarfism, rather than for taxonomic purposes. For example, no differentiation was made between different kinds of projec-

Table 1 . The vegetation zones and habitat categories into which the species were classified. The abbreviations of the different categories are used in tables and figures throughout the paper.

\section{Vegetation zone}

Arctic or Antarctic

Temperate

Temperate montane

Subtropical

Subtropical montane

Tropical

Tropical montane

Tropical alpine

Epiphytism

Epiphytes

Facultative epiphytes

Non-epiphytes
AAR

TEM

TMM

SUB

SUM

TRO

TRM

TRA

EPI

FAC

NON

\section{General habitat}

Epiphyllic, pendent, or branch epiphytes EPB

Stem epiphyte SEP

Epixylic EPX

On rocks ROC

On rocks, wet ROW

On soil SOI

On soil, wet SOW

Shores SHO

Mires MIR

Brooks or rivers BRI

\section{Habitat wetness}

Dry habitats DRY

Wet habitats WET 
tions on the leaf lamina (papillae, mammillae, prorate cell ends). Tables 2 and 3 are self-explanatory except for the following qualitative characters (see Table 2 for character numbers).

(1) Branching pattern and (6) Stem leaf shape. These refer to the erect portions of shoots, that is, the portions directly exposed to the environment. We did not score creeping or firmly attached stems when the plants have in addition erect secondary shoots.

(10) Stem leaf roughness. We scored species as having plicate or transversely undulate leaves both when this was weakly and strongly expressed.

(12) Costa type. In doubtful cases, we interpreted the costa as double when it was indistinct and shorter than $1 / 3$ of the leaf length, unless it was inserted exactly in the middle of the leaf base like in most species with a single costa.

(14) Costa smooth or rough on back. Sometimes dentation or denticulation of the leaf margin continues unmodified on an excurrent costa (e.g., Dichelyma capillaceum). We did not consider this as equivalent with a dorsally rough costa in species with a non-excurrent costa.

(16) Stem leaf margin denticulation. Marginal teeth with two, or sometimes three apices were counted as equal (having the same function), independent of the exact morphology. Such teeth can consist of two adjacent cells, one ad- and one abaxial, or of a single cell with two apices.

(19) Stem leaf basal leaf lamina cell walls incrassate or strongly so and (20) Stem leaf basal leaf lamina cell walls distinctly porose. Cell wall thickness and porosity are best judged in the basal part of the leaves. This is the leaf portion where cells are most consistently thick-walled in species where this is a characteristic, and pores are more easily seen in thick walls than in thin. We here assumed that the states of these characters in the leaf base (excluding the alar region) reflect the conditions also higher up in the leaf, at least in a relative sense.

(25) Paraphyllia present. Heterocladium macounii has papillae on the stem epidermis, which we did not score as paraphyllia.

(26) Rhizoid position (on stems / branches). The rhizoids that are primarily scattered on the stem in, for example, many Calliergonaceae are here interpreted as a result of the plant normally being surrounded by its substrate. There is thus no need to develop primary attachment points, and this condition is joined with the character state 'rhizoids below leaves'.

(39) Capsule orientation in relation to the seta. For the terminology of spore capsule orientation, see Hedenäs (2007).

Data analysis. An excel file ('DWARF_CHARS.xlsx') with the original character and environmental data used in this study is available from the authors. Since the species differed with regard to the completeness of the data and how many characters could be unambiguously referred to either of their states, the numbers of occur- rences available for evaluating the distribution of character states among the sexual systems varied. For qualitative characters and environmental parameters we first tested for differences in frequencies of states among sexual systems with the chi ${ }^{2}$ test applied on $\mathrm{R} \times \mathrm{C}$ contingency tables (Snedecor \& Cochran, 1989), using the Analysis Tools package in Microsoft Excel 2003 SP3. The null hypothesis was that for a certain character or environmental parameter the different states have the same frequency under all sexual systems. When we detected significant differences among the sexual systems, we applied pair-wise chi ${ }^{2}$ tests to evaluate which sexual system differed from each other. The small numbers of expected occurrences in some cases could cause problems with the interpretation of the chi ${ }^{2}$ test results; however, with totals of $>280$ samples in all pair-wise comparisons this is unlikely to be problematic (Snedecor \& Cochran, 1989). Finally, to pin-point which states are most important in explaining significant differences for vegetation zones, general habitats and those morphological characters that have more than two states, we tested the associations of the individual states with the sexual systems with the chi ${ }^{2}$ test in two-way tables with sexual system and states of characters and environmental parameters coded as present or absent, using the crosstabulation option in STATISTICA 10 (StatSoft, 2011).

For quantitative characters the criteria for using Anova to compare the classes were analysed by Brown Forsythe's test of homogeneity of variance and by checking whether the distribution of residuals in preliminary Anovas were normal. Since especially the latter test failed in most cases, we tested for differences among the sexual systems with Kruskal-Wallis Anova by Ranks using STATISTICA 10 (StatSoft, 2011). The statistical significance levels were adjusted by Bonferroni-corrections to avoid the acceptance of chance correlations related to multiple statistical tests.

\section{RESULTS}

Sixteen qualitative ( $41 \%$ of all) and five (55\%) quantitative characters differed significantly among the sexual systems (Tables 2,3). Detailed comparisons among the sexual systems are presented in Figs 1 and 2 for those characters that revealed statistically significant differences among the systems. DIP species differ from those with other sexual systems in more often having broadly cordate (character no. 6) and imbricate stem leaves (11), short and wide marginal leaf cells (15), bi-or multistratose basal and / or alar cells (21), differentiated but not inflated alar cells (22), and patent recurved upper portion of the inner perichaetial leaves (34). On the other hand they have less often ovate-lanceolate stem leaves (6) and undifferentiated alar cells (22) than the other two sexual systems. MON species appeared to be distinctive from both the other two systems in fifteen characters ( 1 , 3, 6, 10, 16, 19, 20, 21, 24, 26, 34, Q2, Q5, Q6, Q7), and DIA species differ from the other two in having an inner perichaetial leaf costa that reaches above mid-leaf (36). 


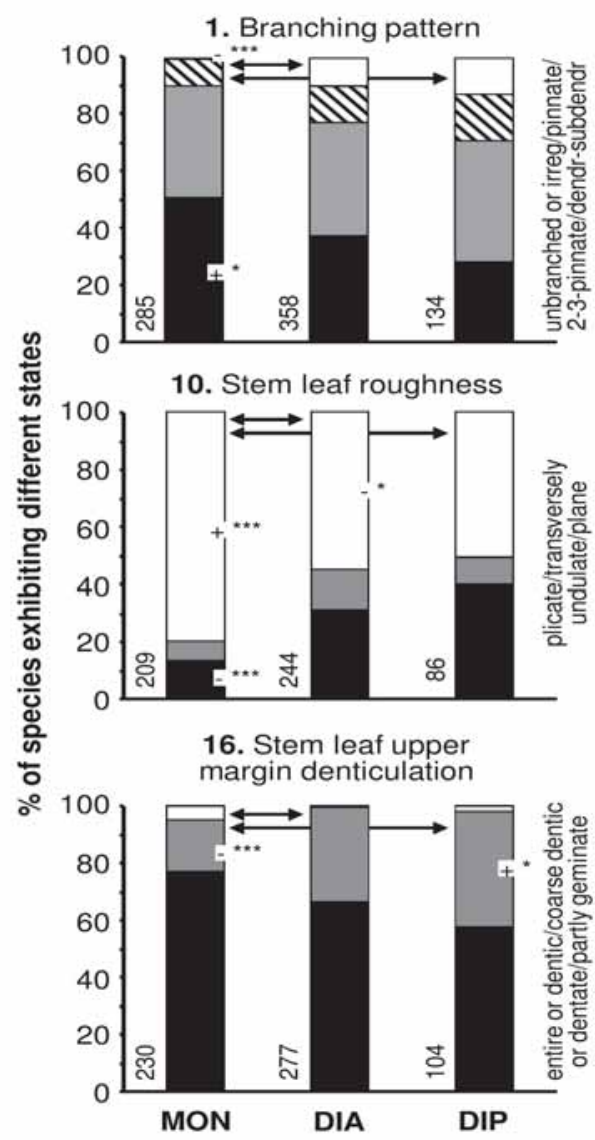

3. Branch curvature (dry)
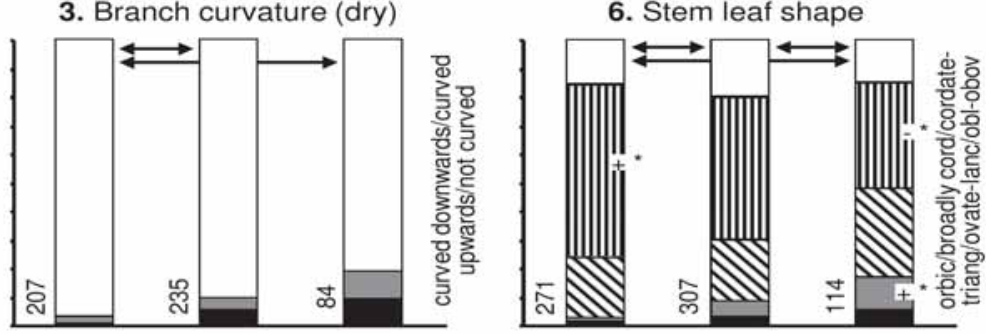

11. Stem leaf orientation

15. Stem leaf marginal cells

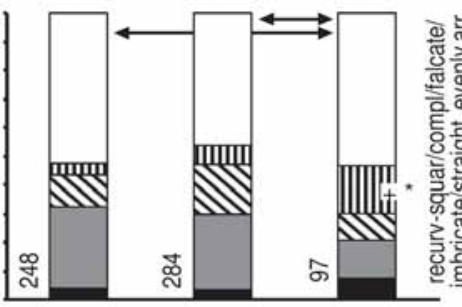

19. Stem leaf basal leaf lamina

cell walls incrassate or strongly so

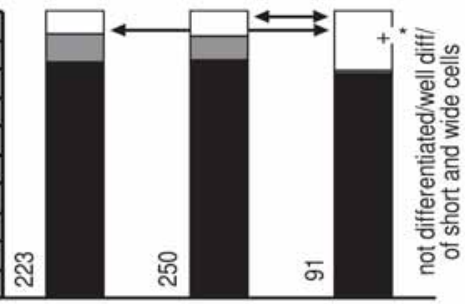

20. Stem leaf basal leaf lamina cell walls distinctly porose
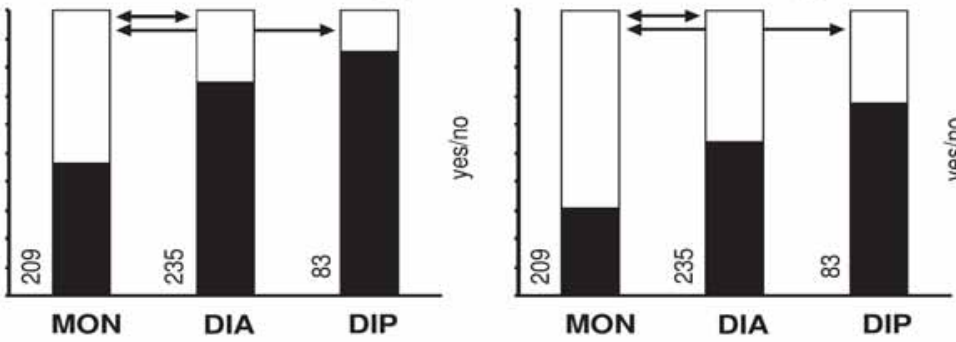

21. Stem leaf basal and / or

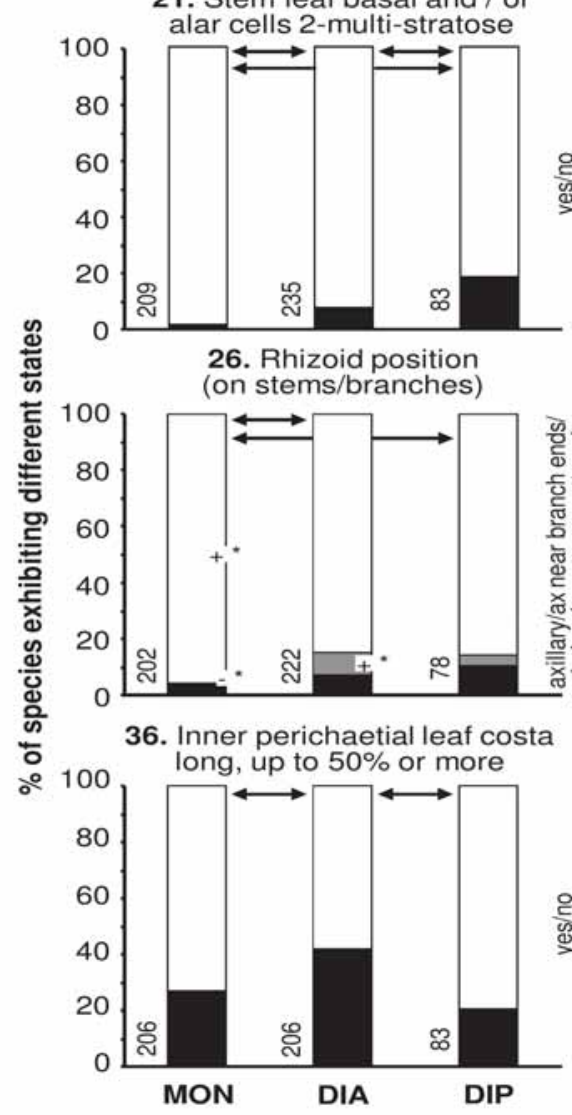

22. Alar cells appearance

24. Pseudoparaphyllia
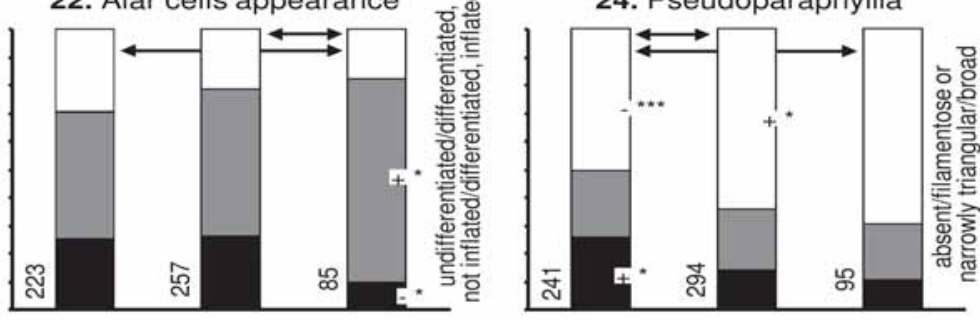

33. Specialized vegetative

34. Upper portion of inner perireproductive units present chaetial leaves patent to recurved
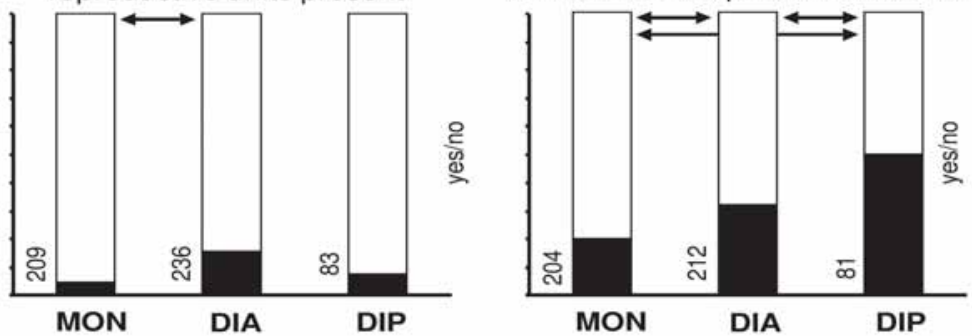

Fig. 1. Percentage distribution of states of qualitative characters within the sexual systems (MON, DIA, DIP, see Material and methods), for the characters that differ between sexual systems (Table 2). The characters are given above the diagrams and the states, corresponding with different shadings or patterns in the

bars, to the right of the right bar (states are listed from the bottom to the top of the

$\stackrel{0}{2}$ bars), sometimes abbreviated compared with Table 2. Sexual systems that differ from each other in pair-wise comparisons are indicated by arrows between the bars. Numbers at the base of the diagrams denote the total number of assignments for the respective sexual system. States that were significantly associated with a sexual system are indicated with a plus or minus and the significance levels from $\mathrm{chi}^{2}$ tests. Asterisks indicate Bonferroni-corrected significance levels corresponding with: * $\mathrm{p}<0.05 ; * * \mathrm{p}<0.01 ; * * * \mathrm{p}<0.001$. 
Table 2. Qualitative characters that, when present, were scored for each taxon, and results of evaluations of the null-hypothesis that MON, DIA, and DIP species (see Material and methods) do not differ regarding the frequency of states of the characters. A indicates that a character is more thoroughly described under Material and Methods. Different states of a character are separated by a slash (/). The chi test was employed to evaluate differences in frequencies of states among classes. Asterisks indicate overall significance levels based on the Bonferroni-corrected $\mathrm{p}(\mathrm{n}=39) ; *<0.001282$ (corresponding to $\mathrm{p}<0.05) ; * * 0.000256(0.01)$; $* * *<0.000026(0.001)$; n.s. $=$ not significant. Pairwise differences among MON, DIA, and DIP species are indicated in Fig. 1 for characters where significant differences were found.

Character

1. Branching pattern ${ }^{\mathrm{A}}$

2. Branches easily detached

3. Curvature of dry branches in relation to substrate

4. Branching angle narrow $\left(<30^{\circ}\right)$

5. Occurrence of red colours

6. Stem leaf shape ${ }^{\mathrm{A}}$

7. Shape of stem leaf apex

8. Presence of apiculus in stem leaves

9. Concaveness of stem leave (leaves strongly concave)

10. Stem leaf roughness ${ }^{A}$

11. Stem leaf orientation

12. Stem leaf costa type ${ }^{\mathrm{A}}$

13. Stem leaf costa length

14. Stem leaf costa at least sometimes dorsally rough ${ }^{\mathrm{A}}$

15. Stem leaf marginal cells

16. Stem leaf leaf upper margin denticulation ${ }^{\mathrm{A}}$

17. Stem leaf margin at least sometimes recurved in $>1 / 2$ its length

18. Median stem and branch leaf lamina cell ornamentation

19. Stem leaf basal leaf lamina cell walls incrassate or strongly $\mathrm{so}^{\mathrm{A}}$

20. Stem leaf basal leaf lamina cell walls distinctly porose $\mathrm{A}^{\mathrm{A}}$

21. Stem leaf basal and/or alar cells 2-multi-stratose yes/no

22. Alar cells appearance

23. Alar cell decurrent $>1 / 4$ down to next leaf

24. Pseudoparaphyllia

25. Paraphyllia present ${ }^{\mathrm{A}}$

26. Rhizoid position (on stems/branches) ${ }^{\mathrm{A}}$

27. Rhizoids initials on the leaves

28. Rhizoid colour

29. Rhizoids strongly branched

30. Rhizoid ornamentation

31. Central strand of stem consistently absent

32. Stem with (partial) hyalodermis or distinctly thin outer cell walls

33. Specialised vegetative reproductive units present yes/no

34. Upper portion of inner perichaetial yes/no leaves patent to recurved

35. Inner perichaetial leaves clearly plicate yes/no

36. Inner perichaetial leaf costa long, yes/no up to $50 \%$ or more

37. Upper perichaetial leaf margin with cilia or cilia-like teeth

38. Vaginular paraphyses absent

39. Capsule orientation in relation to the seta ${ }^{\mathrm{A}}$

yes/no

yes/no

yes/no

yes/no

yes/no

yes/no

yes/no

yes/no

yes/no

yes/no

yes/no

\section{States}

unbranched or irregularly branched/pinnately branched/

bi-or tripinnately branched/dendroid or subdendroid

downwards/upwards-inwards/not curved

Sexual system

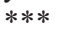

n.s.

$*$

yes/no n.s.

yes/no n.s.

orbicular to suborbicular/broadly cordate or broadly triangular/cordate or $* *$

triangular/ ovate to lanceolate/ oblong to ovate or obovate

acute to broad/acuminate n.s.

yes/no n.s.

yes/no n.s.

plicate/transversely undulate/plane

recurved-squarrose/complanate to subcomplanate/distinctly **

falcate/imbricate/straight, evenly arranged around stem

double or basally forked /single n.s.

$<50 \%$ of leaf length $/ 50-90 \%$ of leaf length/ excurrent (at least sometimes) n.s.

undifferentiated/border well developed, of long and

narrow cells/marginal cells short and (or) wide

entire to denticulate/coarsely denticulate or dentate/

coarse, some teeth with 2(3) apices

smooth/dorsally rough/dorsally and ventrally rough not inflated/clearly differentiated, inflated

absent/filamentose to narrowly triangular/broad

axillary on stem/axillary near branch apices and below

leaves on stem/below leaves or scattered on stem

red-brown/purplish

smooth/granular-papillose/warty-papillose

n.s.

reclinate or antitropous/orthogonal/homotropous/orthotropous

. n.s.

n.s.

n.s.

$* * *$

$* * *$

***

$* *$

n.s.

n.s.

n.s.

n.s.

$*$

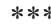

.S.

s.

$* *$

.

.

n.s.

n.s.

n.s. 


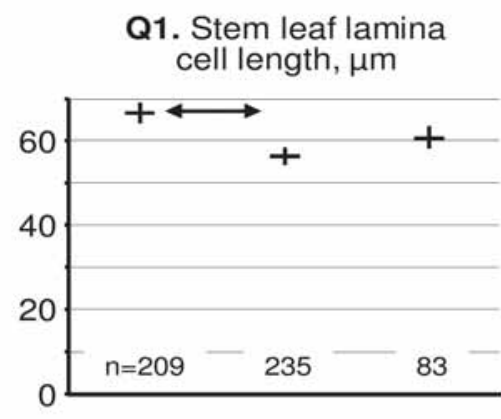

Q6. Number of stem cortex layers

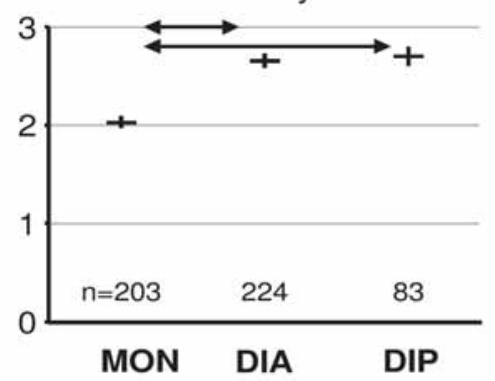

Q2. Stem leaf lamina cell width, $\mu \mathrm{m}$

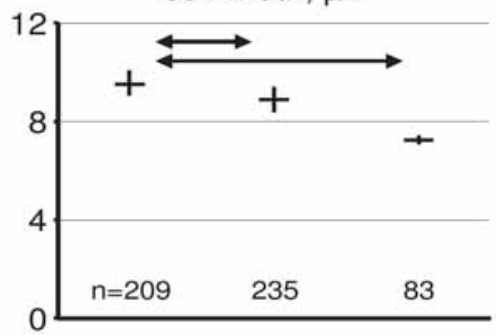

Q7. Length of longest vagin. paraphyses, no. of cells

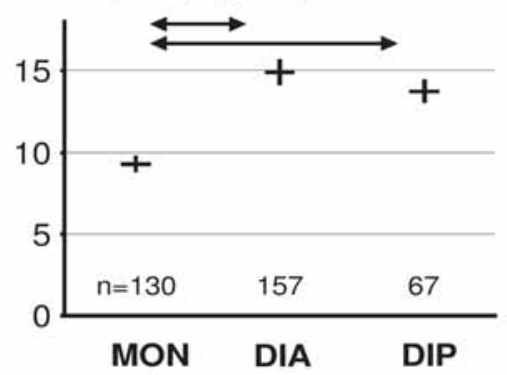

Q5. Axillary hairs, number of upper cells

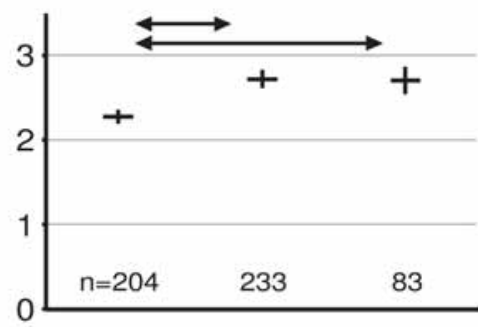

Q8. Seta length, $\mathrm{mm}$

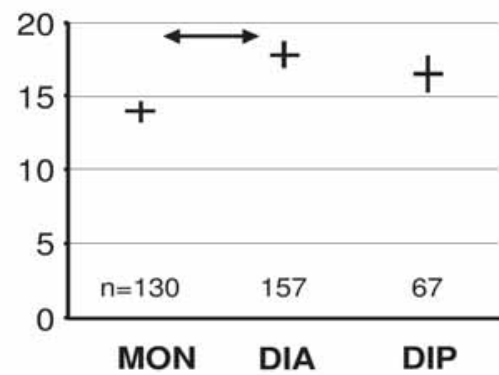

Fig. 2. Mean values (horizontal lines) and Standard Error (vertical lines) for the sexual systems (MON, DIA, DIP, see Material and methods), for those quantitative characters that showed significant deviations from the null hypothesis that the measurements do not differ among the categories (Table 3). Sexual systems that differ from each other in pair-wise comparisons are indicated by arrows between them. Numbers at the base of the diagrams denote the total number of observations for the respective sexual system.

Finally, MON differ from DIA species by more rarely forming specialised vegetative dispersal units (33), longer laminal cells in stem leaves (Q1), and shorter setae (Q8) (Figs 1, 2).

Six out of eight vegetation zone categories differ among the sexual systems. The differences are one (out of 3) for the epiphytism category, two (10) for the general habitat categories, and both for the habitat wetness categories (Fig. 3). DIP species differ from the other two categories in being relatively more abundant than the other sexual systems in the temperate montane zone, rare in brooks and rivers, and more common in dry environments than in wetlands. DIA species are more often non-epiphytes than species of the other two sexual systems (Fig. 3).

\section{DISCUSSION}

We are confident that the 528 species included in this study adequately represent the variation among the three sexual systems of pleurocarpous mosses. They provide the necessary background for future in-depth studies of numerous potential structural and habitat adaptations among selected members or within the entire group. Nevertheless, we need to remember that the presented correlations do not necessarily indicate causal relationships, and that some correlations revealed here may not remain in a phylogenetic context. The potential adaptations discussed below therefore need to be further evaluated by more detailed studies in pleurocarpous moss groups for which phylogenies are sufficiently well known.

Table 3. Quantitative characters that, when present, were scored for each taxon, and results of evaluations of the null-hypothesis that MON, DIA, and DIP species (see Material and methods) do not differ regarding the measurements of the characters. The Kruskal-Wallis ANOVA by Ranks was employed to evaluate differences among classes. Median values of measurements or numbers were used in all analyses except for character Q7, where the largest values were used. Asterisks indicate overall significance levels based on the Bonferroni-corrected $\mathrm{p}(\mathrm{n}=9) ; *<0.005556$ (corresponding to $\mathrm{p}<0.05) ; * *<0.001111(0.01) ; * * *<$ 0.000111 (0.001); n.s. = not significant. Pairwise differences among MON, DIA, and DIP species are indicated in Fig. 2 for characters where significant differences were found.

Q1. Stem leaf lamina cell length $(\mu \mathrm{m})$

Q2. Stem leaf lamina cell width $(\mu \mathrm{m})$

Q3. Ratio stem leaf lamina cell length / width

Q4. Axillary hairs, width of upper cells $(\mu \mathrm{m})$

Q5. Axillary hairs, number of upper cells

Q6. Number of stem cortex layers (excluding hyalodermis)

Q7. Vaginular paraphyses, maximum number of upper cells

Q8. Seta length (mm)

Q9. Spore size $(\mu \mathrm{m})$
Sexual system

$* *$

$* *$

n.s.

n.s

$*$

$* * *$

$* * *$

n.s.

n.s. 

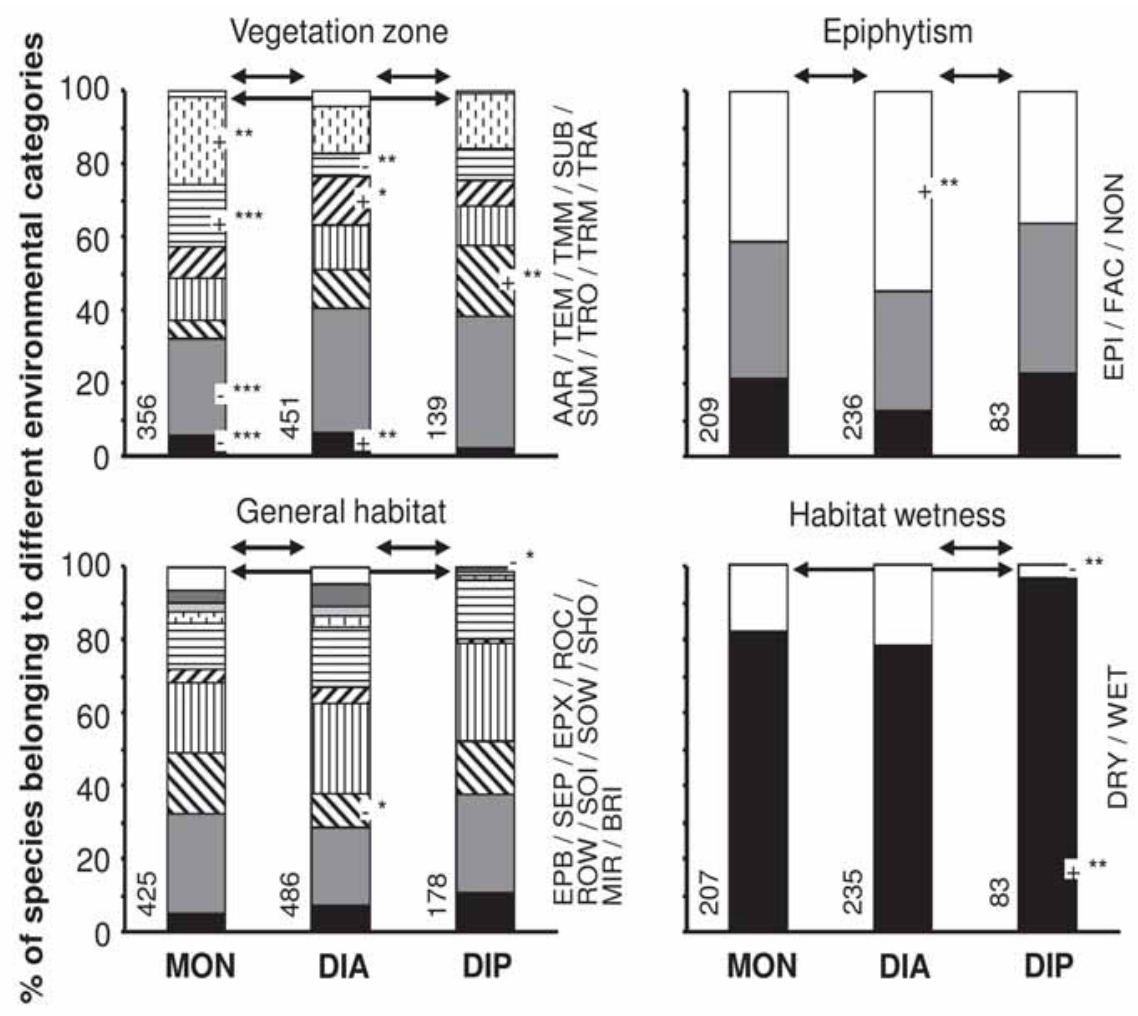

Fig. 3. Percentage distribution of states of vegetation zone and habitat parameters among the sexual systems (MON, DIA, DIP, see Material and methods). The parameters are given above the diagrams and the states, corresponding with different shadings or patterns in the bars, to the right of the right bar (states are listed from the bottom to the top of the bars), abbreviated as in Table 1. Sexual systems that differ from each other in pair-wise comparisons are indicated by arrows between the bars. Numbers at the base of the diagrams denote the total number of assignments for the respective sexual system. States that were significantly associated with a sexual system are indicated with a plus or minus and the significance levels from chi ${ }^{2}$ tests. Asterisks indicate Bonferroni-corrected significance levels corresponding with: $* \mathrm{p}<0.05 ; * * \mathrm{p}<0.01 ; * * \mathrm{p}$ $<0.001$.
Studies concerned with the evolution of dwarf males should preferably concentrate on characters or environments that differentiate DIP species from species with other sexual systems. Further studies may also address the distribution of male dwarfism across the phylogenetic system of mosses. We have previously shown, that DIP species are not evenly spread among the pleurocarpous moss lineages (Hedenäs \& Bisang, 2011). They are more common than expected in the Brachytheciaceae, Lembophyllaceae, Ptychomniaceae, and Sematophyllaceae. On the other hand, they are apparently lacking in other families, such as the Leucodontaceae, Neckeraceae, and Pilotrichaceae.

Do species with dwarf males differ from species without? Character states that are correlated with the DIP sexual system include broad and imbricate leaves, short and wide marginal leaf cells, differentiated, but not inflated alar cells that are relatively often bi- or multistratose, and inner perichaetial leaves with a patent to recurved upper portion. The correlations do not allow distinguishing between the possibilities that these character states represent adaptations for male dwarfism or that they evolved once dwarf males were present. Nevertheless, they could be understood in terms of facilitating the attachment of spores and the establishment of the early protonema on the phorophyte female (During, 1977; Ernst-Schwarzenbach, 1939), or potentially affecting the access to the archegonia in the perichaetia. Imbricate leaves and multistratose alar cells may also ameliorate humidity conditions at the micro scale and thus benefit the establishment and growth of the male plantlets.
Pedersen \& Newton (2007) using a phylogenetic approach, found that three character states (teeth on leaf lamina, mitrate calyptrae, furrowed capsules) were more likely to evolve when dwarf males were present, and dwarf males were more likely to evolve in the presence of rugose leaves and paraphyllia. In addition they reported phylogenetic correlations between dwarf males and germination in relation to dispersal time, perichaetial leaf position on vaginula, leaf rigidity, leaf concavity, leaf plications, leaf rugosity, margin dentation, paraphyllia, and annulus presence. There is little agreement in the characters related to male dwarfism in the two studies. It may be due to different species samples, character definitions, or methodological approaches (phylogenetic vs. statistical correlations). An important aspect is that in this study we consciously selected characters with potential relevance for the evolution of male dwarfism from an extensive database, whereas the selection of Pedersen \& Newton (2007) was wider and less specific, including for example calyptra and sporophytic features. These authors themselves emphasize that their revealed correlations do not necessarily indicate a causal relationship. An evolutionary connection between male dwarfism and, for example, mitrate calyptrae or furrowed capsules, is difficult to explain. The lack of a biologically meaningful explanation for the significant relationship of several of the characters with the evolution of male dwarfism, suggesting that they may be accidental, also requires caution with the interpretation of the other correlations in Pedersen \& Newton (2007).

Out of the 48 scored characters, 18 differed between MON and DIP species compared to 17 differences be- 
tween MON and DIA, and six between DIA and DIP (Figs 1, 2). Whereas the DIP system is more similar to MON than to DIA in a reproductive functional context (Hedenäs \& Bisang, 2011), morphologically the MON system differs equally from both dioicous systems. Thus, despite that the term 'pseudautoicous' is sometimes used for DIP species, these are not intermediate between MON and DIA species in morphology.

DIP species were relatively more abundant than those having other sexual systems in the temperate montane zone and in dry than in wet habitats. This fits with their relative rarity in brooks and rivers, and in wetlands in general, where water for fertilization is freely available. However, no correlation between male dwarfism and epiphytism or subtropical habitats was found, as previously suggested (Pedersen \& Newton, 2007; Ramsay, 1979).

How do monoicous species differ from dioicous species? Numerous characters differentiate monoicous (MON) from the two categories of dioicous species (above, and Figs 1,2), suggesting that certain character states are more advantageous in monoicous than in dioicous systems. Stems of MON species have on the average fewer layers of cortical cells than those of DIA or DIP. Their leaves are more rarely plicate or transversely undulate, exhibit less often denticulate upper margins, have wider leaf lamina cells, and more rarely thick-walled and porose basal leaf lamina cells. Further, dioicous species have longer axillary hairs and vaginular paraphyses than monoicous species. These organs may protect the shoot apex or sexual organs from drying out in dioicous species (Schofield, 1981; Schofield \& Hebant, 1984). The differentiating features include several of those suggested to be related to water availability by Hedenäs (2001). MON species occur relatively more often than DIA and DIP ones in the humid tropical and tropical montane regions (Fig. 3), which may be a reason why they differ from the latter in features likely related to water availability.

Another reason why MON species display fewer states that promote water transport and retention than dioicous species could be that they are less dependent on capillary water for successful fertilization due to relative proximity of female and male reproductive organs on the same individual. For fertilization in dioicous species to occur water must be available as a film or in capillary spaces between individuals, where spermatozoids can swim or be passively transported with the water. More strongly branched shoots in dioicous than monoicous species (Fig. 1, character 1) is also plausible in this context. Especially in DIA species or in DIP ones with only facultative dwarf males numerous branches contribute to form capillary networks that may facilitate fertilization over longer distances (Bisang et al., 2004). Finally, the relatively low frequency of epiphytes among DIA species could be a consequence of the high frequency of DIA species in the Arctic or Antarctic zones and low in the tropical lowlands, where epiphytes are relatively less and more common, respectively.
Conclusions and perspectives for the future. Information on the sexual system is lacking for many bryophytes, in particular for tropical species. Hence, this study includes $15 \%$ fewer species than a similar study where morphological character distribution was investigated in relation to epiphytism (Hedenäs, 2012). Further, for a number of species, we retrieved information on the sexual system from the literature. We have recently revealed that male dwarfism has been overlooked. Therefore, some species now placed in the DIA category may actually belong in the DIP category (Hedenäs \& Bisang, 2011). Nonetheless, we are confident that we satisfactorily captured the variation among the sexual systems of pleurocarpous mosses by scoring a set of 528 species covering the phylogenetic, geographic and environmental range present in the group.

In general, there is no unambiguous picture emerging regarding which sets of morphological and anatomical characters or environmental (including vegetational) parameters correlate with male dwarfism in pleurocarpous mosses, based on this initial study. It appears that male dwarfism has evolved in phylogenetically widely spread groups that are not characterized by common characters or environments. It seems to be a widespread reproductive strategy among mosses to cope with potential disadvantages for successful sexual reproduction based on a high frequency of dioicy, female-dominated sex ratios, and that fertilisation depends on liquid water (Bisang et al., 2004; Bisang et al., 2014; Bisang \& Hedenäs, 2005). Future studies may concentrate on individual families, or well-resolved clades including a few families of pleurocarpous mosses. The present results provide useful information to formulate hypotheses regarding which character states and specific environments are possibly associated with a specific sexual system at a smaller taxonomic scale. In particular, clades lacking male dwarfism may deserve more thorough examination in comparison with sister clades where dwarf males occur. Further advances in our knowledge about dwarf males and their function in the biology of pleurocarpous and other mosses must rely on several lines of investigation: i) careful assessment of additional species, especially from tropical and subtropical regions to gain a more exact figure of the frequency of species that produce dwarf males, especially facultatively (Hedenäs \& Bisang, 2011); further studies along the lines of Pedersen \& Newton (2007) to place the evolution of male dwarfism in a phylogenetic context; iii) an analysis of costs and benefits of monoicy, dioicy with, and dioicy without without dwarf males in different environments; iv) studies aiming at understanding the function of dwarf males in the life histories, habitats, and population genetics of bryophytes (Hedenäs \& Bisang, 2012; Pedersen et al., 2006; Rosengren \& Cronberg, 2014; Rosengren et al., 2014). The latter require innovative approaches, since the dwarf males are both small, sensitive, and grow hidden with- 
in the female tufts or mats. However, the knowledge gained during the last decade provides excellent opportunities to more deeply understand the fascinating and biologically important system of dwarf males that occurs only in some bryophytes among the lineages of green land plants.

\section{ACKNOWLEDGEMENTS}

We thank two anonymous reviewers for comments that improved the text.

\section{LITERATURE CITED}

ARNOLD, E.N. 1994. Investigating the origins of performance advantage: adaptation, exaptation and lineage effects. - In: Eggleton, P. \& R. Vane-Wright (eds.). Phylogenetics and ecology. London, Academic Press: $123-168$.

BELL, N., D. QUANDT, T.J. O'BRIEN \& A.E. NEWTON. 2007. Taxonomy and phylogeny in the earliest diverging pleurocarps: square holes and bifurcating pegs. - Bryologist 110: 533-560.

BISANG, I., J. EHRLÉN \& L. HEDENÄS. 2004. Mate limited reproductive success in two dioicous mosses. - Oikos 104: 291-298.

BISANG, I., J. EHRLÉN, C. PERSSON \& L. HEDENÄS. 2014. Family affiliation, sex ratio and sporophyte frequency in unisexual mosses. Botanical Journal of Linnean Society 174: 163-172.

BISANG, I. \& L. HEDENÄS. 2005. Sex ratio patterns in dioicous bryophytes re-visited. - Journal of Bryology 27: 207-219.

CODDINGTON, J.A. 1994. The roles of homolgy and convergence in studies of adaptation. - In: Eggleton, P. \& R. Vane-Wright (eds.). Phylogenetics and ecology. London, Academic Press: 53-78.

DURING, H.J. 1977. A taxonomical revision of the Garovaglioideae (Pterobryaceae, Musci). - Bryophytorum Bibliotheca 12: 1-244.

EGGLETON, P. \& R. VANE-WRIGHT. 1994. Phylogenetics and ecology. - London, Academic Press. 376 pp.

ERNST-SCHWARZENBACH, M. 1939. Zur Kenntnis des sexuellen Dimorphismus der Laubmoose. - Archiv der Julius Klaus-Stiftung fur Vererbungsforschung, Sozialanthropologie und Rassenhygiene 14: 361-474.

FREY, W. \& M. STECH. 2009. Division of Bryophyta Schimp. (Musci, Mosses). - In: Frey, W. (ed.). Syllabus of plant families. Adolf Engler's Syllabus der Pflanzenfamilien, 13th edition. Part 3. Bryophytes and seedless vascular plants. Berlin, Gebrüder Borntraeger: $116-257$.

GHISELIN, M.T. 1974. The economy of nature and the evolution of sex. - Berkeley, University of California Press. 346 pp.

HARVEY, P.H. \& M.D. PAGEL. 1991. The comparative method in evolutionary biology. - Oxford, Oxford University Press. 239 pp.

HEDENÄS, L. 2001. Environmental factors potentially affecting character states in pleurocarpous mosses. - Bryologist 104: 72-91.

HEDENÄS, L. 2007. Morphological characters and their use in pleurocarpous moss systematics. - Systematic Association Special Volume 71: $221-239$.

HEDENÄS, L. 2012. Morphological and anatomical features associated with epiphytism among the pleurocarpous mosses - one basis for further research on adaptations and their evolution. - Journal of Bryology 34: $79-100$.

HEDENÄS, L. \& I. BISANG. 2011. The overlooked dwarf males in mosses - Unique among green land plants. - PPEES 13: 121-135.

HEDENÄS, L. \& I. BISANG. 2012. Sex expression and sex ratios in dwarf male-producing pleurocarpous mosses - have we missed something? - Plant Ecology and Diversity 5: 387-393.

HO, B.C. 2010. Evolution and diversification of the Hookeriales (Bryopsida) with emphasis on Distichophyllum (Daltoniaceae) and its allied genera ( $\mathrm{PhD}$ thesis). - Bonn, Rheinischen-Friedrich-WilhelmsUniversität Bonn, 154 pp.
LOSOS, J.B. 2008. Phylogenetic niche conservatism, phylogenetic signal and the relationship between phylogenetic relatedness and ecological similarity among species. - Ecology Letters 11: 995-1007.

OLSSON, S., F. RUMSEY, M. GRUNDMANN, S. RUSSEL, J. ENROTH $\&$ D. QUANDT. 2009. The origin of the British and Macaronesian endemic Thamnobryum species (Neckeraceae). - Journal of Bryology 31: $1-10$.

PEDERSEN, N. \& A.E. NEWTON. 2007. Phylogenetic and morphological studies within the Ptychomniales, with emphasis on the evolution of dwarf males. - In: Newton, A.E. \& R.S. Tangney (eds.), Pleurocarpous mosses: systematics and evolution. Boca Raton, CRC Press: 367-392.

PEDERSEN, N., S.J. RUSSELL, A.E. NEWTON \& S.W. ANSELL. 2006. A novel molecular protocol for the rapid extraction of DNA from bryophytes and the utility of direct amplification of DNA from a single dwarf male. - Bryologist 109: 257-264.

PICHONET, A. \& S.R. GRADSTEIN. 2012. Male dwarfism in the genus Dicranum (Dicranaceae) - a review. - Cryptogam., Bryol. 33: 299-311.

RAMSAY, H. 1979. Anisospory and sexual dimorphism in the Musci.In: Clarke, G.C.S. \& J.G. Duckett (eds.). Bryophyte systematics. London, Academic Press: 281-316.

ROSENGREN, F. \& N. CRONBERG. 2014. The adaptive background of nannandry: dwarf male distribution and fertilization in the moss Homalothecium lutescens. - Biological Journal of Linnean Society 113: $74-84$.

ROSENGREN, F., N. CRONBERG, T. REITALU \& H.C. PRENTICE. 2014. Sexual reproduction in the phyllodioicous bryophyte Homalothecium lutescens (Hedw.) H.Rob. in relation to habitat age, growth conditions and genetic variation. - Journal of Bryology 36: 200-208.

SCHOFIELD, W.B. 1981. Ecological significance of morphological characters in the moss gametophyte. - Bryologist 84: 149-165.

SCHOFIELD, W.B. \& C. HEBANT. 1984. The morphology and anatomy of the moss gametophyte. - In: Schuster, R.M. (ed.). New manual of bryology, vol. 2. Nichinan, The Hattori Botanical Laboratory: 627-657.

SNEDECOR, G.W. \& W.G. COCHRAN. 1989. Statistical methods, ed. 8. - Ames, Iowa State University, 503 pp.

STATSOFT, I. 2011. STATISTICA (data analysis software system), Version 10. - www.statsoft.com, accessed 5 March 2014.

VANDERPOORTEN, A., L. HEDENÄS, C. COX \& A.J. SHAW. 2002. Phylogeny and morphological evolution of the Amblystegiaceae (Bryopsida). - Molecular Phylogenetics and Evolution 23: 1-21.

VANDERPOORTEN, A. \& A.-L. JACQUEMART. 2004. Evolutionary mode, tempo, and phylogenetic association of continuous morphological traits in the aquatic moss genus Amblystegium. - Journal of Evolutionary Biology 17: 279-287.

VILHELMSEN, L. \& G.F. TURRISI. 2011. Per arborem ad astra: Morphological adaptations to exploiting the woody habitat in the early evolution of Hymenoptera. - Arthropod Structure \& Development 40: 2-20.

VOLLRATH, F. 1998. Dwarf males. - Trends in Ecology \& Evolution 13: $159-163$.

Appendix 1. Studied species, with the sexual system indicated after their names: MON: monoicous; DIA: dioicous, dwarf males absent; DIP: dioicous, dwarf males present (sometimes the dwarf males are facultative).

Abietinella abietina (Hedw.) M.Fleisch. (DIA); Achrophyllum dentatum (Hook.f. \& Wilson) Vitt. \& Crosby (DIA); A. quadrifarium (Sm.) Vitt \& Crosby (DIA); Acrocladium chlamydophyllum (Hook.f. \& Wilson) Müll.Hal. \& Broth. (MON); Acroporium lamprophyllum Mitt. (DIP); A. longirostre (Brid.) W.R.Buck (MON); A. procerum (Müll.Hal.) M.Fleisch. (DIP); A. strepsiphyllum (Mont.) B.C.Tan (DIP); Actinothuidium hookeri (Mitt.) Broth. (DIA); Adelothecium bogotense (Hampe) Mitt. (DIA); Aerobryopsis parisii (Cardot) Broth. (DIA); A. wallichii (Brid.) M.Fleisch. (DIA); Aerobryum speciosum Dozy \& Molk. (DIP); Aerolindigia 
capillacea (Hornsch.) M.Menzel (MON); Allioniella cryphaeoides Broth. (MON); Amblystegium pseudosubtile Hedenäs (MON); A. serpens (Hedw.) Schimp. (MON); Anacamptodon compactus (Thér.) W.R.Buck (MON); A. cubensis (Sull.) Mitt. (MON); A. splachnoides (Brid.) Brid. (MON); Ancistrodes genuflexa (Müll.Hal.) Crosby (DIP); Andoa berthelotiana (Mont.) Ochyra (DIP); Anomodon attenuatus (Hedw.) Huebener (DIA); A. longifolius (Brid.) Hartm. (DIA); A. rugelii (Müll.Hal.) Keissl. (DIA); Antitrichia californica Sull. (DIA); A. curtipendula (Hedw.) Brid. (DIA); Aptychopsis pyrrophylla (Müll.Hal.) Wijk \& Margad. (MON); Beeveria distichophylloides (Broth. \& Dixon) Fife (DIA); Bestia longipes (Sull. \& Lesq.) Broth. (DIA); Boulaya mittenii (Broth.) Cardot (DIA); Brachytheciastrum collinum (Müll.Hal.) Ignatov \& Huttunen (MON); B. dieckei (Röll) Ignatov \& Huttunen (MON); B. falcatulum (Broth.) Ignatov \& Huttunen (MON); B. paradoxum (Hook.f. \& Wilson) Ignatov \& Huttunen (MON); B. trachypodium (Brid.) Ignatov \& Huttunen (MON); B. velutinum (Hedw.) Ignatov \& Huttunen $(\mathrm{MON})$; Brachythecium albicans (Hedw.) Schimp. (DIA); B. campestre (Müll.Hal.) Schimp. (MON); B. coruscum I.Hagen; B. erythrorrhizon Schimp. (DIP); B. fontanum Fife (MON); B. ruderale (Brid.) W.R.Buck (DIA); B. rutabulum (Hedw.) Schimp. (MON); B. salebrosum (F.Weber \& D.Mohr) Schimp. (MON); Breidleria pratensis (Spruce) Loeske (DIP); Brotherella lorentziana (Lorentz) Loeske (DIP); Bryhnia scabrida (Lindb.) Kaurin (DIA); Brymela parkeriana (Hook. \& Grev.) W.R.Buck (DIA); Bryoandersonia illecebra (Hedw.) H.Rob. (DIP); Bryobrothera crenulata (Broth. \& Paris) Thér. (DIA); Bryolawtonia vancouveriensis (Kindb.) D.H. Norris \& Enroth (DIA); Bryonoguchia molkenboeri (Sande Lac.) Z.Iwats. \& Inoue (DIA); Callicladium haldanianum (Grev.) H.A.Crum (MON); Callicostella papillata (Mont.) Mitt. (MON); C. perpapillata Broth. \& P.de la Varde (MON); C. prabaktiana (Müll.Hal.) Bosch \& Sande Lac. (MON); Callicostellopsis meridensis (Müll.Hal.) Broth. (DIA); Calliergon cordifolium (Hedw.) Kindb. (MON); C. giganteum (Schimp.) Kindb. (DIA); C. megalophyllum Mikut. (DIA); C. richardsonii (Mitt.) Kindb. (MON); Calliergonella cuspidata (Hedw.) Loeske (DIA); C. lindbergii (Mitt.) Hedenäs (DIA); Calyptrochaeta cristata (Hedw.) Desv. (DIA); C. odontoloma (Matteri) Matteri (DIA); Camptochaete arbuscula (Sm.) Reichardt (DIP); C. deflexa (Wilson) A.Jaeger (DIP); C. excavata (Taylor) A.Jaeger (DIA); Campyliadelphus chrysophyllus (Brid.) R.S.Chopra (DIA); C. elodes (Lindb.) Kanda (DIA); Campylium laxifolium Engelmark \& Hedenäs (MON); C. longicuspis (Lindb. \& Arnell) Hedenäs (MON); C. protensum (Brid.) Kindb. (DIP); C. stellatum (Hedw.) C.E.O.Jensen (DIP); Campylophyllum calcareum (Crundw. \& Nyholm) Hedenäs (MON); C. halleri (Hedw.) M.Fleisch. (MON) ; C. hispidulum (Brid.) Hedenäs (MON); C. quisqueyanum (W.R.Buck) Hedenäs (MON); C. sommerfeltii (Myrin) Hedenäs (MON); Caribaeohypnum polypterum (Mitt.) Ando \& Higuchi (DIA); Catagonium nitens (Brid.) Cardot (DIA); C. nitens subsp. maritimum (Hook.) S.H.Lin (DIA); Chaetomitriopsis glaucocarpa (Schwägr.) M.Fleisch. (MON); Chaetomitrium acanthocarpum Bosch. \& Sande Lac. (DIP); C. lanceolatum Bosch \& Sande Lac. (DIP); Chionostomum rostratum (Griff.) Müll.Hal. (MON); Chryso-hypnum frondosum (Mitt.) W.R.Buck (MON); Cirriphyllum piliferum (Hedw.) Grout (DIA); Cladomniopsis crenatoobtusa M.Fleisch. (DIA); Claopodium assurgens (Sull. \& Lesq.) Cardot (DIP); C. whippleanum (Sull.) Renauld \& Cardot (DIA); Clastobryella cuculligera (Sande Lac.) M.Fleisch. (DIA); Clastobryopsis planula (Mitt.) M.Fleisch. (DIA); Clastobryum indicum (Dozy \& Molk.) Dozy \& Molk. (DIA); Climacium dendroides (Hedw.) F.Weber \& D.Mohr (DIA); Colobodontium vulpinum (Mont.) S.P.Churchill \& W.R.Buck (MON); Cratoneuron filicinum (Hedw.) Spruce (DIA); Cratoneuropsis relaxa (Hook.f. $\&$ Wilson) M.Fleisch. var. relaxa (DIA); Crosbya straminea (Beckett) Vitt (DIA); Crossomitrium patrisiae (Brid.) Müll.Hal. (DIA); Cryphaea heteromalla (Hedw.) D.Mohr (MON); C. patens Müll.Hal. (MON); Cryptoleptodon longisetus (Mont.) Enroth (DIA); Cryptopapillaria fuscescens (Hook.) M.Menzel (DIA); Ctenidium capillifolium (Mitt.) Broth. (DIP); C. molluscum (Hedw.) Mitt. (DIP); Curviramea mexicana (Thér.) H.A.Crum (DIA); Cyathophorum bulbosum (Hedw.) Müll.Hal. (DIA); Cyclodictyon albicans (Hedw.) Kuntze (MON); C. blumeanum (Müll.Hal.) Kuntze (MON); C. laetevirens (Hook. \& Tayl.) Mitt. (MON); C. vallis-gratiae (Müll.Hal.) Kuntze (MON); C. varians (Sull.) Kuntze (MON); Daltonia angustifolia Dozy \& Molk. $(\mathrm{MON}) ;$ D. aristata Geh. \& Hampe (MON); D. contorta Müll.Hal. (MON); D. stenophylla Mitt. (MON); Dendrohypopterygium arbuscula (Brid.) Kruijer (DIA); Dichelodontium nitidum (Hook.f. \& Wilson) Broth. (DIA); Dichelyma capillaceum (With.) Myrin (DIA); Dimorphocladon borneense Dixon (DIA); Diploneuron connivens E.B.Bartram (DIA); Distichophyllidium nymanianum M.Fleisch. (MON); Distichophyllum maibarae Besch. (MON); D. mittenii Bosch \& Sande Lac. (MON); D. pulchellum (Hampe.) Mitt. (DIA); D. rigidicaule (Dusén) Broth. (DIA); D. rotundifolium (Hook.f. \& Wilson) Müll.Hal. \& Broth. (DIA); Dolichomitra cymbifolia (Lindb.) Broth. (DIP); Dolichomitriopsis diversiformis (Mitt.) Nog. (DIP); Donnellia commutata (Müll.Hal.) W.R.Buck (MON); Drepanocladus aduncus (Hedw.) Warnst. (DIA); D. angustifolius (Hedenäs) Hedenäs \& C. Rosborg (DIA); D. arcticus (R.S.Williams) Hedenäs (MON); D. brachiatus (Mitt.) Dixon (MON); D. latinervis Warnst. (DIA); D. longifolius (Mitt.) Paris (DIA); D. lycopodioides (Brid.) Warnst. (DIA); D. polygamus (Schimp.) Hedenäs (MON); D. sendtneri (H.Müll.) Warnst. (DIA); D. sordidus (Müll.Hal.) Hedenäs (DIA); D. trifarius (F.Weber \& D.Mohr) Paris (DIA); D. turgescens (T. Jensen) Broth. (DIA); Echinodiopsis hispida (Hook.f. \& Wilson) S.Olsson (DIA), Enroth \& D.Quandt; E. umbrosa (Mitt.) S.Olsson, Enroth \& D.Quandt (DIA); Echinodium setigerum (Mitt.) Jur. (DIA); E. spinosum (Mitt.) Jur. (DIA); Ectropothecium anisophyllum Broth. $(\mathrm{MON}) ;$ E. brachycladulum Broth. (MON); E. leptochaeton (Schwägr.) W.R.Buck (MON); E. plumigerum (Broth.) Hedenäs (MON); Elmeriobryum philippinense Broth. (DIA); Endotrichellopsis laevifolia (Thwaites \& Mitt.) During (DIP); Entodon schleicheri (Schimp.) Demet. (MON); Eumyurium sinicum (Mitt.) Nog. (DIP); Euptychium cuspidatum (Mitt.) Mitt. (DIP); Eurhynchiastrum pulchellum (Hedw.) Ignatov \& Huttunen (DIP); Eurhynchium angustirete (Broth.) T.J.Kop. (DIP); E. asperipes (Mitt.) Dixon (MON); E. crassinervium (Taylor) Schimp. (DIA); E. striatum (Hedw.) Schimp. (DIP); Eurohypnum leptothallum (Müll.Hal.) Ando (DIA); Fabronia pusilla Raddi (MON); Fallaciella gracilis (Hook.f. \& Wilson) H.A.Crum (DIA); Fauriella tenuis (Mitt.) Cardot (DIA); Fifea aciphylla (Dixon \& Sainsbury) H.A.Crum (DIP); Floribundaria floribunda (Dozy \& Molk.) M.Fleisch. (DIA); Fontinalis antipyretica Hedw. (DIA); Forsstroemia indica (Mont.) Paris (DIA); F. remotifolia (Lindb. ex Broth.) Hedenäs \& Zare (DIA); F. trichomitria (Hedw.) Lindb. (MON); Gammiella ceylonensis (Broth.) B.C.Tan \& W.R.Buck (DIA); Garovaglia elegans (Dozy \& Molk.) Bosch \& Sande Lac. subsp. elegans (DIP); G. plicata (Brid.) Bosch \& Sande Lac., s. str. (DIP); Giraldiella levieri Müll.Hal. (MON); Glossadelphus glossoides (Bosch. \& Sande Lac.) M.Fleisch. (MON); Gollania cylindricarpa (Mitt.) Broth. (DIA); G. elbertii Broth. (DIA); G. ruginosa (Mitt.) Broth. (DIA); G. turgens (Müll.Hal.) Ando (DIA); G. varians (Mitt.) Broth. (DIA); Gradsteinia andicola Ochyra; Habrodon perpusillus (De Not.) Lindb. (DIA); Hageniella micans (Mitt.) B.C.Tan \& Y.Jia (DIA); Hamatocaulis lapponicus (Norrl.) He- 
denäs (DIA); H. vernicosus (Mitt.) Hedenäs (DIA); Haplocladium microphyllum (Hedw.) Broth. (MON); H. virginianum (Brid.) Broth. (MON); Hedenaesia austrina (Hook.f. \& Wilson) Huttunen \& Ignatov (MON); H. muriculata (Hook.f. \& Wilson) Huttunen \& Ignatov (MON); Hedenasiastrum percurrens (Hedenäs) Ignatov \& Vanderpoorten (DIA); Helicoblepharum fuscidulum (Mitt.) Broth. (DIA); Helodium blandowii (F.Weber \& D.Mohr) Warnst. (MON); Hemiragis aurea (Brid.) Kindb. (MON); Herpetineuron toccoae (Sull. \& Lesq.) Cardot (DIA); Herzogiella cylindricarpa (Cardot) Z.Iwats. (MON); H. seligeri (Brid.) Z.Iwats. (MON); H. striatella (Brid.) Z.Iwats. (MON); Heterocladium dimorphum (Brid.) Schimp. (DIP); H. heteropterum (Brid.) Schimp. (DIA); H. macounii Best (DIA); H. procurrens (Mitt.) A.Jaeger (DIP); H. wulfsbergii I.Hagen (DIA); Heterophyllium affine (Hook.) M.Fleisch. (MON); Homalia lusitanica Schimp. (DIA); H. webbiana (Mont.) Schimp. (DIA); Homalothecium aeneum (Mitt.) E.Lawton (DIP); H. arenarium (Lesq.) E. Lawton (DIA); H. aureum (Spruce) H.Rob. (DIP); H. californicum Hedenäs et al. (DIP); H. fulgescens (Müll.Hal.) A.Jaeger (DIA); H. laevisetum Sande Lac. (DIP); H. lutescens (Hedw.) H.Rob. (DIP); H. mandonii (Mitt.) Geh. (DIP); H. megaptilum (Sull.) H.Rob. (DIP); H. nevadense (Lesq.) Renauld \& Cardot (DIP); $H$. nuttallii (Wilson) A.Jaeger (DIP); H. philippeanum (Spruce) Schimp. (DIP); H. pinnatifidum (Sull.) E. Lawton (DIP); H. sericeum (Hedw.) Schimp. (DIP); Homomallium incurvatum (Brid.) Loeske (MON); Hookeria lucens (Hedw.) Sm. (MON); Hydropogon fontinaloides (Hook.) Brid. (MON); Hygroamblystegium fluviatile (Hedw.) Loeske (MON); H. humile (P.Beauv.) Vanderpoorten, Hedenäs \& Goffinet (MON); H. tenax (Hedw.) Jenn. (MON); H. varium (Hedw.) Mönk. (MON); Hygrohypnum alpestre (Hedw.) Loeske (MON); H. duriusculum (De Not.) D.W.Jamieson (MON); H. eugyrium (Schimp.) Loeske (MON); H. luridum (Hedw.) Jenn. (MON); H. montanum (Lindb.) Broth. (MON); H. norvegicum (Schimp.) J.J.Amann (MON); H. ochraceum (Wilson) Loeske (DIA); H. polare (Lindb.) Loeske (DIA); H. smithii (Sw.) Broth. (MON); Hylocomiastrum himalayanum (Mitt.) Broth. (DIA); H. pyrenaicum (Spruce) M.Fleisch. (DIA); H. umbratum (Hedw.) M.Fleisch. (DIA); Hylocomiopsis ovicarpa (Besch.) Cardot (DIA); Hylocomium splendens (Hedw.) Schimp. (DIA); Hyocomium armoricum (Brid.) Wijk \& Margad. (DIA); Hypnella leptorrhyncha (Hook. \& Grev.) A.Jaeger (DIA); Hypnodendron dendroides (Brid.) Touw (DIA); Hypnum cupressiforme Hedw. (DIA); H. dieckii Renauld \& Cardot (DIA); $H$. fertile Sendtn. (MON); H. hamulosum Schimp. (DIP); H. imponens Hedw. (DIA); H. jutlandicum Holmen \& Warncke (DIA); $H$. oldhamii (Mitt.) A.Jaeger (DIA); H. pallescens (Hedw.) P.Beauv. (MON); H. plumaeforme Wilson (DIA); H. recurvatum (Lindb. \& Arnell) Kindb. (MON); H. resupinatum Taylor (DIA); H. revolutum (Mitt.) Lindb. (DIA); H. uncinulatum Jur. (DIA); Hypopterygium didictyon Müll.Hal. (DIA); Isopterygiopsis muelleriana (Schimp.) Z.Iwats. (DIA); I. pulchella (Hedw.) Z.Iwats. (MON); Isopterygium brasiliense (Broth.) W.R.Buck (MON); I. elodes P.de la Varde (MON); I. mbangae (Müll. Hall.) A.Jaeger (MON); I. minutirameum (Müll.Hal.) A.Jaeger (MON); I. tenerum (Sw.) Mitt. (MON); Isothecium algarvicum W.E.Nicholson \& Dixon (DIA); I. alopecuroides (Dubois) Isoviita (DIP); I. cristatum (Hampe) H.Rob. (DIP); I. myosuroides Brid. (DIP); I. myosuroides var. brachythecioides (Dixon) C.E.O.Jensen (DIA); I. prolixum (Mitt.) M.Stech et al. (DIP); I. subdiversiforme Broth. (DIP); Kindbergia praelonga (Hedw.) Ochyra (DIA); Lembophyllum clandestinum (Hook.f. \& Wilson) Lindb. (DIP); L. divulsum (Hook.f. \& Wilson) Lindb. (DIP); Lepidopilidium hanningtonii (Mitt.) Broth. (MON); Lepidopilum longifolium Hampe (MON); L. polytrichoides (Hedw.) Brid. (MON); L. scabrisetum
(Schwägr.) Steere (MON); Leptodictyum riparium (Hedw.) Warnst. (MON); Leptodon smithii (Hedw.) F.Weber \& D.Mohr (DIA); Leptohymenium tenue (Hook.) Schwägr. (DIP); Leptoischyrodon congoanus Dixon (MON); Lepyrodon lagurus (Hook.) Mitt. (DIP); Lescuraea patens Lindb. (DIA); Leskea gracilescens Hedw. (MON); Leskeodon andicola (Mitt.) Broth. (MON); Leskeodontopsis pustulata Zanten (MON); Leucodon brachypus Brid. (DIA); L. sciuroides (Hedw.) Schwägr. (DIA); L. treleasei (Cardot) Paris (DIA); Limbella tricostata (Sull.) E.B.Bartram (DIA); Loeskeobryum brevirostre (Brid.) M.Fleisch. (DIA); L. cavifolium (Sande Lac.) Broth. (DIA); Loeskypnum badium (Hartm.) H.K.G.Paul (DIA); L. wickesii (Grout) Tuom.; Looseria orbiculata (Thér.) D.Quandt. et al. (DIP); Lopidium struthiopteris (Brid.) M.Fleisch. (DIA); Macrohymenium muelleri Dozy \& Molk. (MON); Macrothamnium hylocomioides M.Fleisch. (DIP); $M$. javense M.Fleisch. (DIP); M. macrocarpum (Reinw. \& Hornsch.) M.Fleisch. (DIA); Mastopoma armitii (Broth \& Geh.) Broth. (DIP); Meiothecium microcarpum (Harv.) Mitt. (MON); Mesonodon flavescens (Hook.) W.R.Buck (MON); Metaneckera menziesii (Drumm.) Steere (DIA); Meteoriella soluta (Mitt.) S.Okamura (DIA); Meteoriopsis squarrosa (Harv.) M.Fleisch. (DIA); Meteorium polytrichum Dozy \& Molk. (DIA); Microeurhynchium pumilum (Wilson) Ignatov \& Vanderpoorten (DIA); Mittenothamnium reduncum (Mitt.) Ochyra (DIA); Miyabea fruticella (Mitt.) Broth. (DIP); Myurella julacea (Schwägr.) Schimp. (DIA); M. sibirica (Müll.Hal.) Reimers (DIA); M. tenerrima (Brid.) Lindb. (DIA); Myurium hochstetteri (Schimp.) Kindb. (DIP); Myuroclada maximowiczii (G.G.Borshch.) Steere \& W.B.Schofield (DIP); Neckera cephalonica Jur. \& Unger (DIA); $N$. complanata (Hedw.) Huebener (DIA); N. crispa Hedw. (DIA); $N$. douglasii Hook. (DIA); N. intermedia Brid. (DIA); N. pennata Hedw. (MON); N. pumila Hedw. (DIA); Neckeropsis foveolata (Mitt.) Broth. (MON); N. lepineana (Mont.) M.Fleisch. (DIA); N. undulata (Hedw.) Reichardt (MON); Neobarbella comes (Griff.) Nog. (DIP); Neodolichomitra yunnanensis (Besch.) T.J.Kop. (DIA); Nogopterium gracile (Hedw.) Crosby \& W.R. Buck (DIA); Ochyraea tatrensis Váňa (DIA); Oedicladium rufescens (Reinw. \& Hornsch.) Mitt. (DIA); Orontobryum hookeri (Mitt.) M.Fleisch. (DIA); Orthostichella rigida (Müll.Hal.) B.H.Allen \& Magill (DIA); Orthothecium chryseum (Schwägr.) Schimp. (DIA); O. intricatum (Hartm.) Schimp. (DIA); O. rufescens (Brid.) Schimp. (DIA); Oxyrrhynchium hians (Hedw.) Loeske (DIA); O. schleicheri (R.Hedw.) Röll (DIA); O. speciosum (Brid.) Warnst. (MON); Palamocladium euchloron (Müll.Hal.) Wijk \& Margad. (DIP); P. leskeoides (Hook.) E.Britton (DIP); P. wilkesianum (Sull.) Müll.Hal. (DIP); Palisadula chrysophylla (Cardot) Toyama (DIA); Palustriella commutata (Hedw.) Ochyra (DIA); P. decipiens (DeNot.) Ochyra (DIA); P. falcata (Brid.) Hedenäs (DIA); Papillidiopsis luxurians (Dozy \& Molk.) W.R.Buck \& B.C.Tan (DIP); Paranapiacabaea paulista W.R.Buck \& Vital (MON); Pelekium atlanticum (Hedenäs) Hedenäs (MON); P. minutulum (Hedw.) Touw (MON); P. velatum Mitt. (MON); Philophyllum tenuifolium (Mitt.) Broth. (MON); Phyllodon perplanicaulis (Broth.) Kis (MON); P. truncatulus (Müll.Hal.) W.R.Buck (MON); Phyllogonium viride Brid. (DIA); Piloecium pseudorufescens (Hampe) Müll.Hal. (DIP); Pilosium chlorophyllum (Hornsch.) Müll.Hal. (MON); Pilotrichella flexilis (Hedw.) Ĺngström (DIA); P. mauiensis (Sull.) A.Jaeger (DIA); Pilotrichidium antillarum Besch. (DIA); Pilotrichum compositum (Hedw.) P.Beauv. (DIA); P. procerum Mitt. (DIA); Pinnatella alopecuroides (Mitt.) M.Fleisch. (DIA); P. mucronata (Bosch \& Sande Lac.) M.Fleisch. (DIA); Plagiothecium curvifolium Limpr. (MON); P. denticulatum (Hedw.) Schimp. (MON); P. georgicoantarcticum (Müll.Hal.) Kindb. (MON); P. latebricola 
Schimp. (DIA); P. neckeroideum Schimp. (DIA); P. nemorale (Mitt.) A.Jaeger (DIA); P. nitidifolium (Mitt.) A.Jaeger (MON); $P$. piliferum (Sw.) Schimp. (MON); P. undulatum (Hedw.) Schimp. (DIA); Plasteurhynchium meridionale (Schimp.) M.Fleisch. (DIP); P. striatulum (Spruce) M.Fleisch. (DIP); Platydictya jungermannioides (Brid.) H.A.Crum (DIA); Platygyriella densa (Hook.) W.R.Buck (DIA); Platygyrium repens (Brid.) Schimp. (DIP); Platylomella lescurii (Sull.) A. L. Andrews (MON); Pleuroziopsis ruthenica (Weinm.) E.Britton (DIA); Pleurozium schreberi (Brid.) Mitt. (DIA); Porothamnium panduraefolium (Müll.Hal.) M.Fleisch. (DIA); Prionodon densus (Hedw.) Müll.Hal. (DIA); Pseudoamblystegium subtile (Hedw.) Vanderpoorten \& Hedenäs (MON); Pseudobarbella ancistrodes (Renauld \& Cardot) Manuel (DIA); P. attenuata (Thwaites \& Mitt.) Nog. (DIA); Pseudocampylium radicale (P.Beauv.) Vanderpoorten \& Hedenäs (MON); Pseudohypnella verrucosa (Dozy \& Molk.) M.Fleisch. (MON); Pseudoleskeella catenulata (Schrad.) Kindb. (DIA); Pseudoleskeopsis zippelii (Dozy \& Molk.) Broth. (MON); Pseudopiloecium mamillisetum Zanten (MON); Pseudoscleropodium purum (Hedw.) M.Fleisch. (DIA); Pseudotaxiphyllum elegans (Brid.) Z.Iwats. (DIA); P. pohliaecarpum (Sull. \& Lesq.) Z.Iwats. (DIA); Pterigynandrum filiforme Hedw. (DIA); Pterobryella longifrons (Müll.Hal.) A.Jaeger (DIA); Pterogonidium pulchellum (Hook.) Müll.Hal. (MON); Pterogoniopsis cylindrica Müll.Hal. (MON); Ptilium crista-castrensis (Hedw.) De Not. (DIA); Ptychomnion aciculare (Brid.) Mitt. (DIP); Pylaisiadelpha tenuirostris (Sull.) W.R.Buck (DIP); Pylaisia polyantha (Hedw.) Schimp. (MON); Pylaisiopsis speciosa (Mitt.) Broth. (MON); Pyrrhobryum spiniforme (Hedw.)Mitt. (MON); Racopilum cuspidigerum (Schwägr.) Ĺngstr. (DIP); R. spectabile Reinw. \& Hornsch.; Radulina borbonica (Bél.) W.R.Buck (MON); R. hamata (Dozy \& Molk.) W.R.Buck \& B.C.Tan (MON); Rauiella scita (P.Beauv.) Reimers (MON); Regmatodon orthostegius Mont. (MON); Renauldia mexicana (Mitt.) H.A.Crum (MON); Rhizofabronia perpilosa (Broth.) Broth. (MON); R. sphaerocarpa (Dusén) M.Fleisch. (MON); Rhizogonium distichum (Sw.) Brid. (DIA); Rhynchostegiella jacquinii (Garov.) Limpr. (MON); R. litorea (De Not.) Limpr. (MON); R. macilenta (Renauld \& Cardot) Cardot (MON); R. tenella (Dicks.) Limpr. (MON); Rhynchostegium celebicum (Sande Lac.) A.Jaeger (MON); R. confertum (Dicks.) Schimp. (MON); R. confusum K. Cezón, J. Muńoz, Hedenäs \& Huttunen (MON); R. cylindritheca Dixon (MON); $R$. distratum (Hampe) A.Jaeger (MON); R. laxatum (Mitt.) Paris (MON); R. megapolitanum (F.Weber \& D.Mohr) Schimp. (MON); R. murale (Hedw.) Schimp. (MON); R. mutatum (Ochyra \& Vanderpoorten) Huttunen \& Ignatov (MON); R. nanopennatum (Broth.) Kindb. (MON); R. riparioides (Hedw.) Cardot (MON); R. tenuifolium (Hedw.) Reichardt (MON); Rhytidiadelphus japonicus (Reimers) T.J.Kop. (DIA); R. loreus (Hedw.) Warnst. (DIA); R. squarrosus (Hedw.) Warnst. (DIA); R. subpinnatus (Lindb.) T.J.Kop. (DIA); R. triquetrus (Hedw.) Warnst. (DIA); Rhytidiopsis robusta (Hook.) Broth. (DIP); Rhytidium rugosum (Hedw.) Kindb. (DIA); Rigodium implexum Schwägr. (DIP); $R$. pseudothuidium Dusén (DIP); $R$. toxarion (Schwägr.) A.Jaeger (DIP); Rutenbergia madagassa Geh. \& Hampe (DIA); Sanionia nivalis Hedenäs (MON); S. orthothecioides (Lindb.) Loeske (MON); S. symmetrica (Renauld \& Cardot) Wheld. (MON); $S$. uncinata (Hedw.) Loeske (MON); Sarmentypnum exannulatum (Schimp.) Hedenäs (DIA); S. procerum (Renauld \& Arnell) Hedenäs (DIA); S. sarmentosum (Wahlenb.) Tuom. \& T.J.Kop. (DIA);
S. trichophyllum (Warnst.) Hedenäs (DIA); S. tundrae (Arnell) Hedenäs (DIA); Sauloma tenella (Hook.f. \& Wilson) Mitt. (DIA); Schimperobryum splendidissimum (Mont.) Margad. (DIA); Schoenobryum concavifolium (Griff.) Gangulee (MON); Schraderella pungens Müll.Hal. (MON); Schroeterella zygodonta Herzog (MON); Sciuro-hypnum flotowianum (Sendtn.) Ignatov \& Huttunen (DIA); S. hylotapetum (N.L. Higinb. \& B.L. Higinb.) Ignatov \& Huttunen (DIA); S. plumosum (Hedw.) Ignatov \& Huttunen (MON); S. populeum (Hedw.) Ignatov \& Huttunen (MON); Scleropodium obtusifolium (Mitt.) Kindb. (DIA); $S$. touretii (Brid.) L.F.Koch (DIA); Scorpidium cossonii (Schimp.) Hedenäs (DIA); S. revolvens (Sw. ex Anonymo) Rubers (MON); S. scorpioides (Hedw.) Limpr. (DIA); Scorpiurium circinatum (Brid.) M.Fleisch. \& Loeske (DIA); S. cucullatum (Hampe) Hedenäs (MON); S. deflexifolium (Solms.) M.Fleisch. \& Loeske (DIA); Sematophyllum lonchophyllum (Mont.) J.Florsch. (MON); S. pacimoniense (Mitt.) J. Florsch. (MON); S. saproxylophilum (Müll.Hal.) M.Fleisch. (MON); S. subhumile subsp. japonicum (Broth.) Seki (MON); S. subpinnatum (Brid.) E.Britton (MON); S. subsimplex (Hedw.) Mitt. (MON); S. substrumulosum (Hampe) E.Britton (MON); Serpoleskea confervoides (Brid.) Loeske (MON); Spiridens camusii Thér. (DIA); Stenodictyon wrightii (Sull. \& Lesq.) Crosby (MON); Stereophyllum radiculosum (Hook.) Mitt. (MON); Straminergon stramineum (Brid.) Hedenäs (DIA); Struckia argentata (Mitt.) Müll.Hal. (MON); Taxiphyllum taxirameum (Mitt.) M.Fleisch. (DIA); T. wissgrillii (Garov.) Wijk \& Margad. (DIA); Taxithelium merrillii Broth. (MON); $T$. nepalense (Schwägr.) Broth. (MON); T. planum (Brid.) Mitt. (MON); T. rotundatulum Broth. (MON); T. werneri (Herzog) Broth. (MON); Tetrastichium fontanum (Mitt.) Cardot (DIA); $T$. virens (Cardot) S.P.Churchill (DIA); Thamniopsis cheiloneura (Broth.) W.R.Buck (MON); T. incurva (Hornsch.) W.R.Buck (MON); T. undata (Hedw.) W.R.Buck (MON); T. utacamundiana (Mont.) W.R.Buck (MON); Thamnobryum alopecurum (Hedw.) Gangulee (DIA); T. maderense (Kindb.) Hedenäs (DIA); T. pandum (Hook.f. \& Wilson) I.G.Stone \& G.A.M.Scott (DIA); Thelia asprella (Schimp.) Sull. \& Lesq. (DIP); Thuidium delicatulum (Hedw.) Mitt. (DIA); T. furfurosum (Hook.f. \& Wilson) Reichardt (DIA); T. pristocalyx (Müll.Hal.) A.Jaeger (DIA); T. tamariscinum (Hedw.) Schimp. (DIA); Timotimius titanotus W.R.Buck (MON); Tomentypnum falcifolium (Nichols) Tuom. (DIA); T. nitens (Hedw.) Loeske (DIA); Trachyloma indicum Mitt. (DIA); Trachyphyllum inflexum (Harv.) A.Gepp (DIA); Trachythecium verrucosum (A.Jaeger) M.Fleisch. (MON); Trachyxiphium subfalcatum (Hampe) W.R.Buck (MON); Trichosteleum boschii (Dozy \& Molk.) A.Jaeger (MON); T. mammosum (Müll.Hal.) A.Jaeger (MON); T. papillosum (Hornsch.) A.Jaeger (MON); Tripterocladium leucocladulum (Müll.Hal.) A.Jaeger (DIP); Trismegistia rigi$d a$ (Mitt.) Broth. (DIA); Trolliella euendostoma Herzog (MON); Vesicularia dubyana (Müll.Hal.) Broth. (MON); V. galerulata (Duby) Broth. (MON); V. oreadelphus (Broth.) Broth. (MON); V. soyauxii (Müll.Hal.) Broth. (MON); V. vesicularis (Schwägr.) Broth. (MON); Vesiculariopsis spirifolium (Dusén) Broth. (MON); Vittia pachyloma (Mont.) Ochyra (DIA); Warburgiella cuspidatifolia M.Fleisch. (MON); Warnstorfia fluitans (Hedw.) Loeske (MON); W. pseudostraminea (Müll.Hal.) Tuom. \& T.J.Kop. (MON); Weymouthia cochlearifolia (Schwägr.) Dixon (DIP); W. mollis (Hedw.) Broth. (DIP); Wijkia extenuata (Brid.) H.A.Crum (DIA); W. tanytricha (Mont.) H.A.Crum (DIP); W. trichocolea (Müll.Hal.) H.A.Crum (MON). 